\title{
Ethnopharmacological Studies of Argemone Mexicana for the Management of Psoriasis Followed By Molecular Techniques: Focus on Plant Metabolomics \& Mechanism of Action
}

\author{
Mohammad Gayoor Khan, Yezdani Umama, Hari Baskar, Kumar Ayush, Karthikeyan Lakshman, \\ Monika Sekar
}

\begin{abstract}
Psoriasis is an autoimmune condition which results in the body attacking itself. It occurs in the age group of 14 to $\geq 65$ years. The average age is 28 years. More than 10 million cases per year in India are being recorded. Around $15 \%$ of cases emerge before the age of 10 years. In the case of psoriasis, white blood cells known as $T$ cells mistakenly attack the skin cells. Around $80 \%$ of people have mild psoriasis, and the other $20 \%$ have moderate to severe psoriasis. There are different types of psoriasis they are Plaque psoriasis occurs in about $80-90 \%$ of people, it appears as raised, inflamed, red lesions, covered by a silvery, white scales, usually on the elbows, knees, scalp, and lower back. Inverse psoriasis appears in the different parts like armpits, the groin, under the breasts, and in other skin folds such as the buttocks and around the genitals. Argemone Mexicana (Mexican poppy, Mexican prickly poppy, flowering thistle, cardo or cardosanto) is a species of poppy found in Mexico and now widely naturalized in many parts of the world. An extremely hardy pioneer plant as it is tolerant of drought and poor soil, often being the only cover on new road cuttings or verges. The flower has bright yellow latex, and though poisonous to grazing animals and is rarely eaten, but has been used medicinally by many people including those in its native area, the Natives of the western US, parts of Mexico and in Whole part of India, Pakistan, Nepal, Bhutan, etc.
\end{abstract}

Keywords: Chromatographic and Spectrophotometric techniques, Psoriasis, Argemone Mexicana, Albino Mice, Etc

\section{INTRODUCTION}

$\mathbf{P}_{\text {soriasis is a very common Tropical Neglected Disease in }}$ India more than 10 million cases per year are being observed. It causes the cell to build up rapidly on the surface of the skin and itchy or dry patches something painful.

Revised Manuscript Received on July 12, 2019.

* Correspondence Author

Mohammad Gayoor Khan, Department of Pharmacy, Truba Institute of Pharmacy, Bhopal (Madhya Pradesh), India.

Yezdani Umama, Department of Pharmacy Practice, MRM College of Pharmacy, Hyderabad (Telangana), India

Hari Baskar, Department of Pharmaceutical Chemistry, KMCH College of Pharmacy, (Tamil Nadu), India

Kumar Ayush, Department of Pharmacy Practice, (M.M.C.P) M.M.D.U Mullana Ambala (Haryana), India.

Karthikeyan Lakshman, Department of Pharmacy Practice, Raos College of Pharmacy, Nellore (Andhra Pradesh), India.

Monika Sekar, Department of Pharmacy Practice, Raos College of Pharmacy, Nellore (Andhra Pradesh), India.

(C) The Authors. Published by Blue Eyes Intelligence Engineering and Sciences Publication (BEIESP). This is an open access article under the CC BY-NC-ND license (http://creativecommons.org/licenses/by-nc-nd/4.0/)
Psoriasis is chronic Disease it can be for years and lifetime lab test must be required Psoriasis treatments include steroid creams, occlusion, light therapy and oral medications, such as biologics. There are mainly five different types of psoriasis: plaque, guttate, inverse, pustular, and erythrodermic.

Psoriasis Diagnoses based on Patient Symptoms but if Person with Darker skin the patches may be purple in color. The skin can trigger psoriatic skin changes at that spot referred to as the "Koebner phenomenon ". Recently, the worldwide prevalence of psoriasis in adults ranged from $0.53 \%$ to $13.43 \%$. C-reactive protein (CRP) is a key biomarker of acute-phase systemic inflammation and risk for future vascular disease. It can be diagnosed by the elevated level of CRP which is used as a predictor of inflammation in different diseases, including psoriasis. It was found that the level of CRP increases with the increasing number of signs of metabolic syndrome. Psoriasis is referred to as a multisystem chronic disease connected to different co morbidities like obesity. Obesity is a relevant risk factor for the development and complication onset of non-communicable diseases.

Signs and Symptoms: Sometimes psoriasis cause itching on the affected part of the skin, nails, and scalp which is referred to Plaque Psoriasis which is most common Psoriasis, treatment may not scientifically proved but management is possible which is totally depends upon patient past records or Medical history. The goals of treatment are very few, less severe flare-ups. Light therapy: If the rash is more widespread, may treat it with ultraviolet light.

Biologic drugs: Another kind of systemic drug also targets your immune system. Biologic drugs used to treat psoriasis include adalimumab (Humira), etanercept (Enbrel), Brodalumab (Siliq), guselkumab (Tremfya), infliximab (Remicade), ixekizumab (Taltz), secukinumab (Cosentyx), and ustekinumab (Stelara). They're given either by a shot or through a vein in the arm. They have affect on specific type of immune cell or keep certain proteins from causing inflammation. But these drugs can make it harder to fight infection.

Systemic drugs: plaque psoriasis may need medicines that work throughout the body. They calm the immune system or make skin cells grow more slowly. But they cause serious side effects, such as depression, aggressive thoughts, liver problems, or a higher risk of skin cancer.

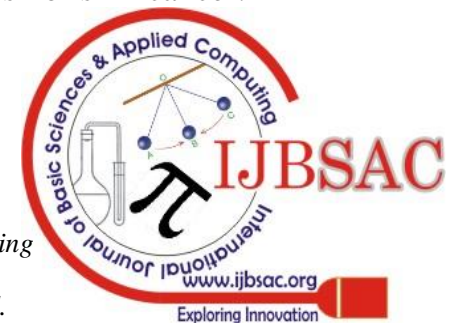




\section{Ethnopharmacological Studies of Argemone Mexicana for the Management of Psoriasis Followed By Molecular Techniques: Focus on Plant Metabolomics \& Mechanism of Action}

Plaque psoriasis: Tropical treatments especially cream are first preference it helps to reduce skin inflammation and minimize cell growth in skin example includes Vitamin A, Vitamin D, Corticosteroid, etc.

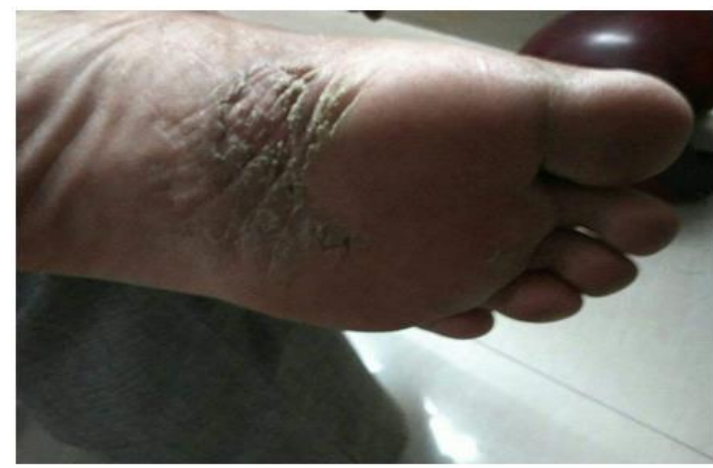

Figure 1.1 Psoriasis on sole of foot

Psoriasis Vulgaris (which is also known as chronic stationary psoriasis or plaque-like psoriasis) is the most common form and affects $85 \%-90 \%$ of people with psoriasis. Plaque psoriasis is typically appeared as raised areas of inflamed skin covered with silvery white scaly skin. These areas are called plaques and are most commonly found on the elbows, knees, scalp, and back.

Psoriasis can affect the nails and produces a variety of changes in the appearance of finger and toenails which occurs in $40-45 \%$ of people with psoriasis affecting the skin and has a lifetime incidence of $80-90 \%$ in those with psoriatic arthritis. These changes include dent in the nails (i.e., pinhead-sized depressions) in the nails is seen in $70 \%$ with nail psoriasis.

\section{BACKGROUND}

Plants are being used in traditional medicine for several thousand years. The knowledge of medicinal plants has been collected since many centuries based on different medicinal systems like (Ayurveda, Unani, and Siddha). It has been reported that traditional healers in India use 2500 plants species of plants and 100 species of plants serve as regular and continuing sources of medicine. In the last few decades, there has been increased interest in the study of medicinal plants and their traditional use in different parts of the world documenting the indigenous knowledge by ethno botanical
Salicylic acid and coal tar also used in the management of psoriasis and few Natural ingredients for smooth itch like Aloe vera gel etc. Topical emollients that put on after a shower or bath can help keep the skin moist.

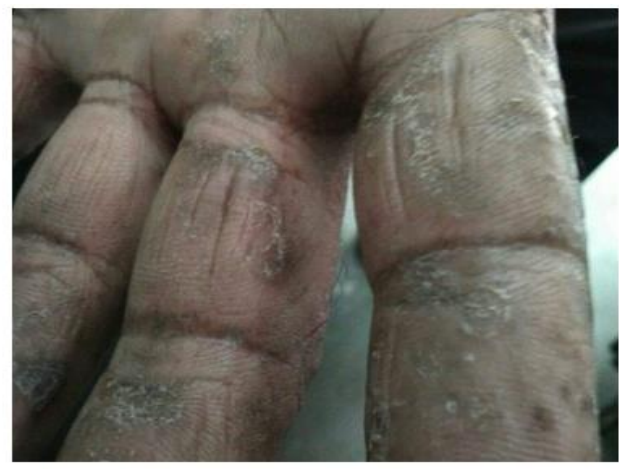

Figure 1.2 Psoriasis on Palms

studies is an important aspect for the conservation and utilization of biological resources. The important thing is the World Health Organization (WHO) shows that as many as $80 \%$ of the World's people depends on traditional medicine for their preliminary health care needs. Major parts of the world's population in developing countries still relay plants for their primary healthcare systems to treat Psoriasis.

The Ethno pharmacological is the Ethno pharmacology (occasionally also called ethno pharmacy) is a related study of ethnic groups and their use of drugs. It is undoubtedly linked to medicinal plant use, ethno botany, as this is the main delivery of pharmaceuticals. It deals with the study of the pharmaceutical means considered in relation to the cultural contexts of their use, for example, Argemone Mexicana is used in Plaque and guttate Psoriasis. Ethno medicinal Plant Argemone Mexicana used for the treatment of Psoriasis diseases.

The botanical name, family name \& Plant characters Argemone Mexicana L. Papaveraceae Prickly, annuals, flowers bright yellow, fruits prickly with blackish-brown seeds.

Local name, English name \& Plant photo - Mexican poppy, Mexican Prickly Poppy, Flowering thistle, Sathyanashi (Hindi) The name Sathyanashi is given because of its ability to successfully treat and cure diseases.

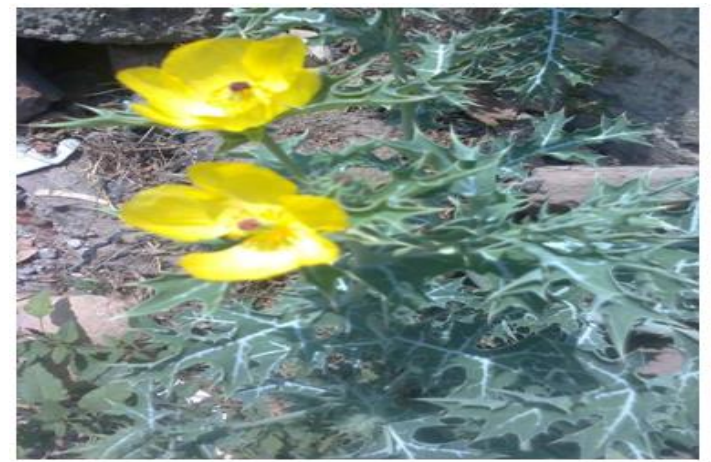

Figure 1.3

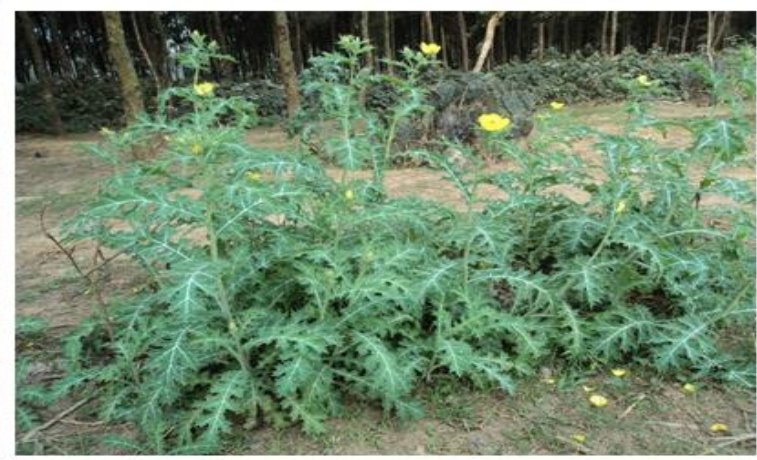

Figure 1.4

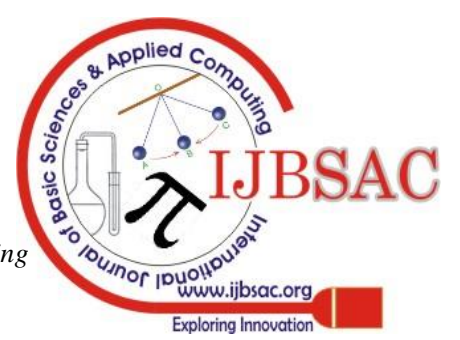


Tribes name - Meena \& Gurjar, Bhil etc.

Plant parts used \& mode of use - Fresh plant sap and paste of root powder applied externally

Districts/ Area- Madhya Pradesh, Uttar Pradesh, Rajasthan

(Chhatarpur M.P, Kota, Bundi, Jhalawar Rajasthan)

Remarks - Very effective in plaque and guttate Psoriasis.

\section{OBJECTIVE SELECTION OF ARGEMONE MEXICANA}

1. To provide treatment that is natural with least side effects

2. To provide a better and effective treatment for the skin diseases like psoriasis.

3. Regulate a cost effective treatment.

4. To provide a treatment with less time duration.

5 . To reduce the cost of treatment.

6 . To increase the quality of life of the patient

7. To provide treatment which can easily be used by everyone.
A. Parameters:
1) Polaration of the scales.
2) Appearance of the scales.
3) Immunohistopathology.
4) Histopathology (skin).
5) Percentage \% scales reduction.
B. Materials and Methods

HPTLC (High Performance Thin layer chromatography)

\section{Study Design}

This is the prospective study on randomly selected samples from patient of different age over a period of 3-4 months using analysis as a tool.

The Research will be conducted in Truba Institute of Pharmacy, Bhopal, Madhya Pradesh, India.

\section{Methodology}

Induction of psoriasis: psoriasis is Included among the wistar rates by the application of $5 \%$ imiquimod cream directly on the skin surface of the animal for 6-9 Days.

Induction of Psoriasis Model: The hairs from the back of the rates are removed using hair removing cream. 5\% imiquimod cream is then applied gently over the surface for 6-9 Days.

This result in the development of the Psoriasis.

\section{E. Collection of Data}

1. The data is being collected from the previous reviews and is analyzed and then the experimentation will begin.

2. Data from the diseases patients.

3. Psoriasis Samples from various areas of Bhopal, Hyderabad India.

\section{F. Inclusion Criteria}

1. Patients with skin infections.

2. Patients with chronic diseases.

3. Patient requiring for long term therapy.

4. Patient of every age group.

5. Patients with recurrent hygiene routine.

G. Exclusion Criteria

1. Species / common name :- Albino Mouse
2. To targets the mechanism of action: focus on Yeast based model protocols along with preclinical studies on animals.

\section{MANAGEMENT OF PLAQUE PSORIASIS :( A New Approach) \\ FORMULATION OF CREAM 20 MG USING EXTERNALLY IN MANAGEMENT OF PLAQUE PSORIASIS}

Materials required - salicylic acid, aloe vera gel, distilled water, argemone Mexicana.

Procedure -

5\% Salicylic acid, $5 \mathrm{Mg}$ Aloe vera gel, Distilled water, Prepared Thick gel from root Argemone mexicana as per followed standard Guideline of Indian Pharmacopoeia Commission.

Dosing and dosage form - Twice a days, externally applied on marks.

Side Effects - There are no side-effects observed in 3 months study.

Although it has not been clinically proven cure of psoriasis but this formulation helps in its management and minimizes the psoriasis in its early stage.

\section{RESULT}

The present study documented an Argemone Mexicana plant commonly used by the indigenous people of Rajasthan as anti-psoriatic. The findings documented in Figure 1.3 to Figure 1.4 and for easy identification of used plants, their photographs have also been given. Hence, this research proves that Argemone Mexicana can be used in the management and treatment of psoriasis in a more effective way and with minimum side effect at a minimal cost to the patient.

\section{CONCLUSION}

Natural medicines such as herbal medicines are a safer mode of therapy because of its presumed lack of adverse side effects. The value of medicinal plants as herbal remedies is being lost due to lacking of awareness, and deforestation. There are more than 19 Types of Natural medicine Plant including Argemone Mexicana, Adiantum incisum, Adiantaceae, Aloe vera, Annona squamosa L, Aristolochia bracteolata, Cannabis sativus, Capsicum, Cassis auriculata, Holoptelea integrifolia, Momordica charantia, Ocimum canum, etc are helpful in the management of Six Different types of Psoriasis Naturally. first Government Or state government should implement take immediate action to Preserve the knowledge of medicinal Plants species and herbal remedies for the overcome of side effects it is very essential and it also helps in Homeopathic, Unani, Ayurveda, Siddha, and Allopathic Formulations.

\section{ACKNOWLEDGMENT}

First of all I would like to Thank my Co- Author Ms. Umama Yezdani (Department of clinical and Pharmacy Practice) MRM college of Pharmacy Hyderabad, India.

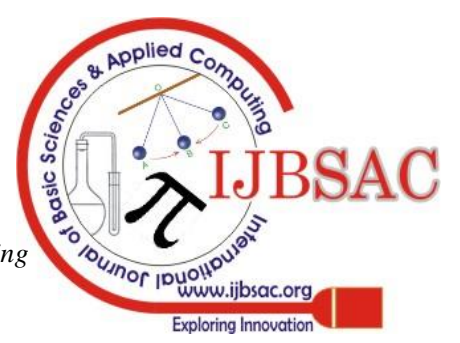




\section{Ethnopharmacological Studies of Argemone Mexicana for the Management of Psoriasis Followed By Molecular Techniques: Focus on Plant Metabolomics \& Mechanism of Action}

The authors are thankful to Dr. Rajesh Singh PAWAR, PhD. Principal Truba Institute of Pharmacy for ceaseless encouragement during the study. We are also thankful to Prof. Sharad Prakash Panday for all time support. Thanks are also extended to Prof.Vinod Dhote Department of Pharmaceutics Truba Institute of Pharmacy Bhopal MP, Prof. Md. Anayatullah Associate Professor Truba Institute of Pharmacy, Bhopal Madhya Pradesh, Dr. N Ganesh Senior Scientist Department of oncology Cancer Hospital Bhopal, MP for their support during at the time of study and identifying the plant for Psoriasis cure and Management.

\section{REFERENCES}

1. Manmohan Singhal \& Niraj Kansara. Cassia tora L. Cream inhibits ultraviolet-B-induced psoriasis in Rats http./www.hinddawl.com/Journals/ISRN/2012/346510. ISRN Dermatology., 2012; 1-5. Article ID 346510, 6 pages.

2. Kameshwari, Shiva, M.N. \& G. Paramasivam. Urginea indica and its role in psoriasis: A review. Int. J. Pharm. \& Life Sci., 2012; 3(12): 2236-2242.

3. Isha Pandey, V. D. Bohra, Ajay Bhargave and Krishnendra Singh Nama. Ethnomedicinal important Plant's of Rajasthan used Disease the treatment of psoriasis Disease : www.wjps.com/Research Article ; ISSN 2277 - 7105 WJPS., 2016(5); 3 846-859.

4. Albuquerque, U.P., M.A. Ramos \& J.G. Melo. New strategies for drug discovery in tropical forests based on ethnobotanical and chemical ecological studies. J. Ethanopharmacol., 2012; 140: 197201.

5. James Kenney. Sarsaparilla (Smilax officinalis) as a treatment Psoriasis .http:/healthpsych.psy.vanderbitt.edu/15/2008/sarsaparilla.htm.

6. Vijaylakshmi, A. Psoriasis treatment. http:/www.life-saving-natural cures-and-naturalremedies.com/natural-cures-for.psoriasis.httml., 2012.

7. Shaikh, Gazi, Sadath Ali, S.Y. Talmale \& S. Ulhas, Surwase. Alternative medicines for psoriasis - Natural herbal, Ayurvedic treatment - A review. Int. J. Ayurvedic \& Herb. Med., 2012; 2(3): 455-463.

8. Vijaylakshmi, A. \& M. Geetha. Psoriasis treatment with pure Aloe vera plant. http./www.miracleplant-aloevera.com/psoriasis.treatment.html., 2012-15; 1-3.

9. Salihbegovic, E.M.; Hadzigrahic, N.; Cickusic, A.J. Psoriasis and metabolic syndrome. Med. Arch. 2015, 69, 85-87. [CrossRef] [PubMed]

10. Borska, L.; Andrys, C.; Krejsek, J.; Palicka, V.; Chmelarova, M.; Hamakova, K.; Kremlacek, J.; Fiala, Z.Oxidative Damage to Nucleic Acids and Benzo(a)pyrene-7,8-diol-9,10-epoxide-DNA Adducts and Chromosomal Aberration in Children with Psoriasis Repeatedly Exposed to Crude Coal Tar Ointment and UV Radiation. Oxid. Med. Cell. Longev. 2014, 2014, 302528.

11. Langan, S.M.; Seminara, N.M.; Shin, D.B.; Troxel, A.B.; Kimmel, S.E.; Mehta, N.N.; Margolis, D.J.;Gelfand, J.M. Prevalence of metabolic syndrome in patients with psoriasis: A population-based study in the United Kingdom. J. Investig. Dermatol. 2012, 132, 556562.

12. Vadakayil, A.R.; Dandekeri, S.; Kambil, S.M.; Ali, N.M. Role of Creactive protein as a marker of disease severity and cardiovascular risk in patients with psoriasis. Indian Dermatol. Online J. 2015, 6, 322-325.

13. A. Balci, D. D. Balci, Z. Yonden et al., "Increased amount of visceral fat in patients with psoriasis contributes to metabolic syndrome," Dermatology, vol. 220, no. 1, pp. 32-37, 2010.

14. S. Coimbra, H. Oliveira, F. Reis et al., "C-reactive protein and leucocyte activation in psoriasis vulgaris according to severity and therapy," Journal of the European Academy of Dermatology and Venereology, vol. 24, no. 7, pp. 789-796, 2010.

15. M. Rajappa, S. Rathika, M. Munisamy, L. Chandrashekar, and D. M. Thappa, "Effect of treatment with methotrexate and coal tar on adipokine levels and indices of insulin resistance and sensitivity in patients with psoriasis vulgaris," Journal of the European Academy of Dermatology and Venereology, vol. 29, no. 1, pp. 69-76, 2015.

16. Shetty, B.V. \& V. Singh. Flora of Rajasthan, 1987; 91 \& 93: Vol. I, II \& III, Botanical Survey of India, Calcutta.

\section{AUTHORS PROFILE}

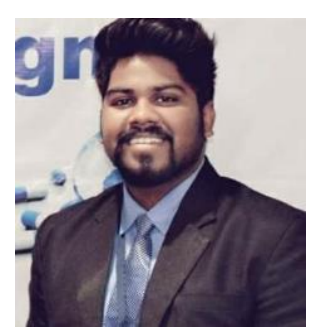

Mohammad Gayoor Khan is B. Pharm from Truba Institute of Pharmacy, Bhopal MP (Certified Dual Course Medical Writing and Clinical Research) From Physis Learning Academy New Delhi. He is Founder and National President of NFPS ( PSCWS), liaison officer at Student Chapter University sains, Malaysia, Ambassador RSTMH London, United Kingdom, Central Executive Council Member IHPA-SF ( Government Professional body for Hospital Pharmacist), He is life Member in Various International or National Professional bodies like IPGA, SPER, IPA, SAS, NFPS, IHPA, APTI, ISPOR,RSTMH ,IPSF, etc. He is Board / Reviewer /Editorial Member of various International Journals like [ JETIR ] [ IJPAR ] [ IJCIRAS ] [ IJPRDEDI ] [ JAPSR ] . He has won various International Award like Young Researcher Award in $21^{\text {st }}$ and $22^{\text {nd }}$ September 2018, Dubai, Best UG Award 23-24 Feb 2019, Vardha Mumbai India by SPER, Youth icon best organising Secretary Award on 16 March 2019 By Bioleagues Pvt. Ltd. , Young Academic Entrepreneurship Award in $9^{\text {th }} 2019$ June Taj Hotel Assam by SAS Society etc. Mohammad Gayoor has Published More than 16 International Publication \& 1 National Publication in Reputated Journals like Thomson Reuters, Elsevier, WJPPS, IJPSR, IJRM, etc. He Won more than 4 Prize which includes $1^{\text {st }}, 2^{\text {nd }}$, 3rd in international and National Conference in Poster or oral Presentation. His Research Area is Tropical Neglected Disease, Skin Disease, Breast cancer, Sexual Disease, etc. Mr. Khan is also Conducted More than 12 International and National conference/Symposium/workshop /Blood Donation camp, Health camp etc, he also attend 12 international conferences, 8 National, 6 Workshop, etc.

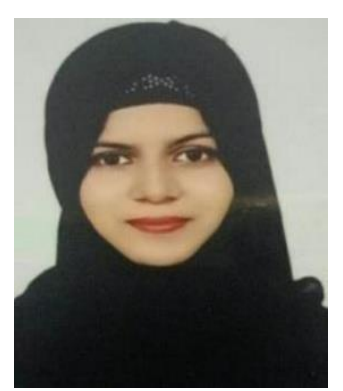

Ms. Umama Yezdani is Perusing [Pharm.D] "P.G course from University of Jawaharlal Nehru Technological University Hyderabad [JNTUH]" from MRM College of Pharmacy Ibrahimpatnam Ranga reddy Dist. Hyderabad, India. She is Doing Internship in Thumbay Hospital, Hyderabad, Telangana. She is Co- Founder of NFPS, Business Associate in Baris Pharmaceutical Pvt. Ltd, Training Associate in Clinitech Pvt. Ltd, Ambassador Inclination Pvt. Ltd. Vice President of SPER-SF (Society of Pharmaceutical education and research. She is state executive council Member in IHPA - SF Indian Hospital Pharmacist Association Gov't Professional Body of IPCA [Indian Pharmacy congress Association]. She is joint secretary in GOMHA (student wing).She is Life Member of SPER, NFPS, IHPA, SAS, and ISPOR Card Carrying Member USA etc. She is Board Member of ( IJCRP ), She won Various international Awards in the field of Healthcare like Best Student Award at international Pharmaceutical Summit held on 18 August 2018 organized by NFPS Central Chapter, Young Clinical Researcher Award at $5^{\text {th }}$ International Conference on $16^{\text {th }}$ March 2019 Jakarta indonesia organized by Biolegues Pvt. Ltd World Wide. Ms. Umama Yezdani Have Published More than 8 international Papers in Reputated Journal's like Thomson Reuters, Elsevier, WJPPS, IJPSR, IJRM, etc. Ms. Yezdani Conduct More than 6 health camp and awareness campaign in Telangana she is also served as state Chairman NFPS Telangana. She Won 1st Prize in Poster Presentation in National Conference at Sagar college of Pharmacy Bhopal MP, Her Research Area is Neurology, Nano Medicine, Neuroscience, Cardiovascular Disease, Blood Cancer, Collen cancer, etc. Ms. Umama Yezdani conducted in past 2 international Conference and one international Pharmaceutical summit in Hyderabad, she attend 15 International conferences, 8 National conferences, 9 Workshops, etc.

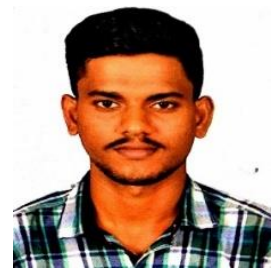

Hari Baskar.B is B.Pharm from KMCH college of pharmacy, Coimbatore, Tamilnadu. He is NFPS West zone President. Member in ISTE (Indian Society for Technical Education) student chapter and organized various programs in the college. He served as a team leader in Swachh Bharat summer internship clean India

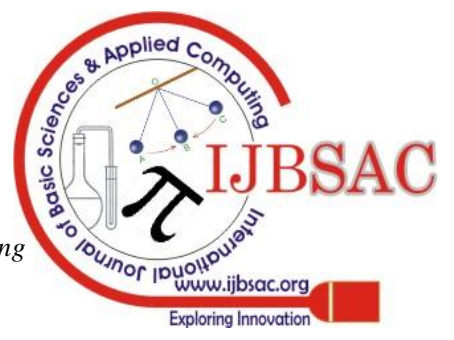


program and involved in many social activities in the villages and government schools under NSS (National Service Scheme). He won cash prize in academic excellence for two years. His current project was selected and funded by TANSCST (Tamilnadu State Council for Science and Technology) and published a research article. Awarded cash prize for his excellent performance in ALL INDIA PHARMACY QUIZ. He got Frist prize in poster presentation in National Pharmacy Week organized by ISTE. He cracked GPAT (Graduate Pharmacy Aptitude Test). He was awarded many prizes in sports meet. His research areas include Molecular Docking, Proteomics, Genomics, Combinatorial Chemistry etc. He attended more than 5 National conferences, 4 workshops and 1 International summit.

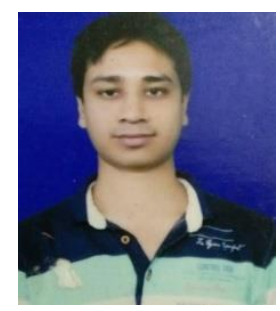

Ayush Kumar currently student at the Doctor of pharmacy, Maharishi Markandeshwar University, Mullana. Ayush does research in Cardiothoracic Surgery, Cardiology and Addiction Medicine.Mr.kumar intrest in ADR/ Pharmacovigillance /clinical research and Patient Safety, He is CEC Member of NFPS, life member RSTMH etc. He attended more than 7 international Conference and National Conference. Mr. Kumar recently conducted as a organizing secretary Conference in Bihar in Association RSTMH, federal body World Health Organization.

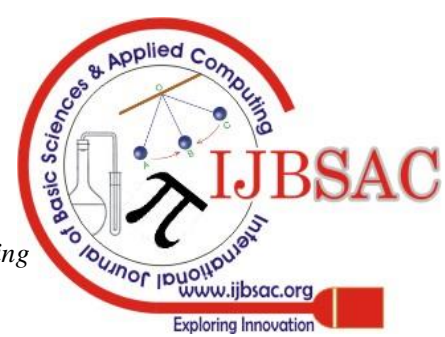

